\title{
Halal Meat Supply Chain Traceability Based on HACCP, Blockchain and Internet of Things
}

\author{
A. Rejeb \\ Széchenyi István University, Department of Logistics and Forwarding \\ Egyetem tér 1, 9026 Győr, Hungary \\ e-mail: abderrahmen.rejeb@gmail.com
}

Abstract: Recently, Halal food has drawn remarkable attention of many consumers around the world. Besides to being unsafe, Halal food such as meat can encounter several issues throughout its supply chain and logistics. At any time, Halal integrity is not guaranteed and risks of becoming non-Halal is the major concern of all parties along the supply chain. To respond to Muslim consumers' trust concerns in Halal food, many traceability systems were proposed in previous studies based on emerging technologies and recommended to be incorporated into Halal food supply chains. Nevertheless, all of these systems are centralized, opaque and not enough transparent. To mitigate these problems, blockchain technology is introduced as a ground-breaking innovation with greater decentralization, visibility and transparency. This paper makes a major contribution in suggesting Halal meat supply chain traceability system for real-time food tracing based on embedding Islamic dietary law into HACCP, blockchain and Internet of Things.

Keywords: Halal Meat Supply Chain; HACCP; Blockchain; Internet of Things; Traceability

\section{Introduction}

Generally, food supply chains are highly characterized by their complexity. In fact, products associated with food supply chains are scattered at each stage of production and between vast networks of different concealed actors for both supplier and consumer. This raises the question of managing effectively food supply chains as there are a huge concern and upsurge for not only food safety but for ensuring food compliance to certain religious restrictions as well. In fact, different religious groups are restrained to their own food restrictions and pay influential roles to prevent their followers from certain foods [1] such as Jews for Kosher, the prohibition of beef- 
eating under Hinduism, and the Islamic Dietary Laws [2]. Besides, the consumers' decision to purchase food is not only guided by the perception of healthiness, safety and sensory traits (i.e., color, tenderness, flavor, and aroma) but by the strict compliance to religion [3]. In this respect, the Muslims' viewpoint to purchase some kind of food depends exclusively on its Halal status. Similarly, food turns from being sustenance to an integral dimension of culture and identity which impacts greatly supply chains and logistics.

Consumers' awareness and education of Halal foods grow together with a noticeable increase in the demand for Halal products on a global scale. Today, Halal foods are no longer considered as religious requirements for Muslims but nonMuslims are also involved in demanding and supplying this particular food group due to many reasons [4]. Moreover, aside from the response to the increasing pace of Muslim population, Halal products, especially food products account for a staggering US\$600 billion to US\$2.1 trillion [5]. This is consistent with [6] [7] [8] who claimed that non-Muslim consumer segment perceives Halal foods beyond the limit of religion. According to [6] [9] Halal status is a global symbol for food safety, quality insurance, and lifestyle choice. Furthermore, the Halal food industry has been globalized due to tourism and migration [10]. Plus, previous studies have demonstrated that Muslims are resistant to acculturation and attached to their ethos and religious dietary laws. Simply stated, they still eat Halal even after having immigrated to Non-Muslim countries. A study carried out by Hussaini showed that $75 \%$ of Muslims in the US still maintain their Islamic eating rules [11].

The increasing popularity of Halal food industry is not only attributable to the additional and value-added features of being safe, wholesome, hygienic and contamination-free principles during food production [12]. It is due to the market attractiveness and involvement of non-Muslim countries in supplying food products to Muslims. Argentina, Australia, Brazil, Canada, New Zealand, the United Kingdom and the United States are the major food producers and suppliers of many Muslim countries [13]. Hence, the globalized nature of Halal supply chains opens up windows of chances for many actors to join the lucrative industry. Billions of customers are targeted by Halal food companies and governments across the world are recognizing the potential of the Halal industry through the continuous support and promotion. This is manifested also by the establishment of Halal certification authorities, the material incentives for funding research on Halal related studies through universities and research centers as well as the offer of Halal training for industry practitioners [14]. Besides, Halal food industry leads to positive externalities in the development of Halal traceability and tracking systems to strengthen food industry and to alleviate all the probable risks and concerns. 
There are many ethical and social questionable activities that transcend the layers of the food supply chain. In this vein, retailers in the food industry are facing challenges of foodborne diseases and are struggling to figure out the source of defective ingredients and to which stores they were delivered [15]. Also, consumers' confidence in the food industry was heavily decoyed after consecutive food safety scandals and frauds, namely mad cow disease, genetically modified foods and the European horse meat scandal in 2013. Not only that, Halal food industry may encounter several issues related to Halal integrity which could be questionable and even breached throughout the phases of supply chain and thus the product will be no longer fit for consumption by Muslim consumers. Several problems may put Halal products into the integrity question. From raw material until it reaches consumers, Halal food may encounter the risk of cross-contamination with Haram products, the non-compliance to Halal slaughtering and ill-intentions. Therefore, there is a problem of distrust to Halal supply chain actors. In response to confidence in Halal food products, Halal logo or certification on the product packaging is presented as the best way to inform the consumers about the compliance of food products to the Halal guidelines and Sharia law principles. Halal logos become very popular to allow customers to crosscheck Halal integrity of the product and support the purchasing decision for both Muslims and Non-Muslims [14]. However, possibilities of misleading consumers through fake logo or certificates are still present. This is because there are various Halal authorities or agencies in some Muslim and nonMuslim countries which resulted in multiple Halal standards and doubtful Halal certifications [16].

To mitigate the risks of Halal meat supply chain, a level of collaboration between the different partners of the chain should be maintained to ensure the trustworthiness of Halal food integrity. This implies to say that a trustful platform based on exchanging information, mutuality, and transparency entails mutual benefits across the whole Halal chain. In a similar way, many technologies are applied to Halal supply chain traceability and visibility in tandem with responding to these concerns. In their studies, Tan et al., Bahrudin et al., and Anir et al. emphasized strongly the adoption of information and communication technology (ICT) for Halal transportation such as Global Positioning System (GPS), Radio Frequency Identification (RFID), and Internet of Things (IoT) to monitor Halal logistics activities. Since the adoption of technology into Halal logistics and supply chain has gained recognition [14], the scope of this study is to propose a supply chain traceability system for Halal meat based on embedding Islamic dietary law into Hazard Analysis and Critical Control Points (HACCP) approach for application to Halal production and processing, Blockchain (BC) and Internet of Things (IoT).

Notwithstanding the potential of the novel BC technology to leverage the use of tracking systems such as RFID technology, this research topic remains overlooked 
and unaddressed by academic researchers. BC is an emerging technology presented to ensure the storage of all information related to the food products in a shared, visible and transparent system for all the members along the supply chain [15]. Several BC projects have been implemented to track and trace the movements of food products throughout the stages of the supply chain and consequently to ensure the integrity of food products.

This paper will discuss Halal meat supply chain. Hence, it begins with a review of the concept of Halal and the relevant issues pertaining to the supply chain and logistics of Halal meat. The next section will present the typical design of Halal meat supply chain along with a process flow and relevant Halal critical points are identified with an example of HACCP management. The following section will introduce the details of the BC-based system with a discussion about the critical role of this technology to enforce customers' trust in Halal meat supply chain. The last section covers a brief conclusion for the paper.

\section{Literature Review}

Halal is an Arabic word and it refers to the Islamic belief. Halal means all things and actions permitted by the Sharia (i.e., Islamic law). Similarly, Halal is an object or an action which is allowed or lawful to be used or taken according to the Islamic law [17]. The antonym of Halal is Haram which means prohibited or forbidden or unlawful. The ideas of Halal and Haram are clearly defined within the Islamic teachings and it is very important to understand that the scope of Halal is so wide since it is a way of life and embraces good conduct and righteous deeds [18]. Besides, Halal status extends also to lifestyle (such as clothing) and services (Islamic finance, hospitality, and logistics, etc) [19]. In the context of food, the Islamic law demonstrates that it is mandatory and crucial for Muslims to consume only Halal (permitted) food and to abstain from any activities that are or will lead to Haram. It is extensively mentioned in the Quran (The holy book) and the Sunnah the guidelines for Halal food:

"Forbidden to you is that which dies of itself, and blood, and the flesh of swine, and that on which any other name than that of Allah has been invoked, and the strangled (animal) and that beaten to death, and that killed by a fall and that killed by being smitten with the horn, and that which wild beasts have eaten, except what you slaughter, and what is sacrificed on stones set up (for idols) and that you divide by the arrows; that is a transgression." (The Quran: Al-Maedah 5:3)

Simply stated, Halal food should be acceptable (i.e., Sharia-compliant) and of good quality, wholesome and safe. Alcohol, pork, blood, dead meat, and meat which has not been slaughtered according to Islamic rulings are all considered Haram [20]. 
With respect to meat, Halal status is not just limited to the application of the ritual Islamic slaughter method, but additional conditions should be taken into account for meat to become Halal [20]. According to Tieman, Halal products or services do not only matter during the point of consumption or purchase but they transcend all the activities of the supply chain from farm-to-fork [21]. In other words, Halal status should be preserved through all the supply chain and Halal product should be protected throughout a series of movement from one supply chain channel to another channel until it reaches the ultimate customer [6]. This implies to say that Halal meat consumers have become increasingly aware and concerned about the integrity of Halal-meat related products with regard to their production, their distribution and their storage along the whole supply chain network. This could be also explained by the selective purchasing decision of Halal consumers, especially Muslims, for checking the components of the foods or drinks to ensure its non-containing of prohibited and Haram items. These latters can be split into many categories and they include any products derived from or contaminated with proscribed materials, such as, carrion, blood, pig, permitted animals slaughtered incorrectly, and intoxicants [18].

The slightest presence of non-Halal elements will breach the Halal status, thus this indicates the sensitivity and the criticality of Halal meat supply chain [14]. Kadir et al. divided Halal poultry meat supply chain into three main processes: the preslaughtering, the slaughtering and the post-slaughtering process [22]. The same rationale could be used in describing the different issues in Halal meat supply chain.

The pre-slaughtering stage involves any activities related to the rearing and fattening of livestock. The production of Halal meat is distinguished from any other type of foods by the inclusion of Halal feeding of livestock and the monitor of livestock health at farms [23]. Any ill or contaminated livestock should be isolated from the cattle and farmers have to keep a medical record of livestock relating to illness, medical treatments, and treatment results during the growing period [23]. Besides, any medical treatments and vaccination which contain pork enzymes make livestock non-Halal and unfit for consumption. Livestock farms should be safe and not within the vicinity of pig farms or run-off from pig farms [18]. It is also worth mentioning that Halal animals may become Haram during breeding in case the animals are supplied with any product derived from Haram sources or obtained biotechnologically through genetic engineering using ingredient and components from Haram species [24] [25]. In doing so, Halal will be humane to animals (i.e., free from epidemics, illnesses, and injuries) and environmentally friendly in addition to the healthiness, wholesomeness, and cleanness of meat. As a result, how the animals are housed, reared and fattened is the primary concern to ensure that the animal welfare is respected and the first steps of supply chain foundation are compliant to Halal guidelines. 
Slaughtering is a very critical stage in Halal meat supply chain. The animals must be slaughtered according to the Sharia principles. They consist of reciting a special prayer "In the name of Allah, Allah is the Greatest" by a practicing Muslim, cutting all four tubes or vessels [18] by a sharp and clean knife which must be invisible to each slaughtered livestock, and a full bleeding of blood after slaughtering [4]. However, the use of stunning methods are very common in most non-Muslim countries (e.g., Western European countries) where there is a non-ritual slaughter that might kill the animal before slaughter and consequently render this meat prohibited or Haram [26]. Although mechanical or machine slaughter of birds is gaining acceptance among Muslims, it is undeniable that some Muslims prefer to purchase their Halal meat directly from the slaughterhouse or buy the animals from the farmer to slaughter themselves at home (which is an illegal practice in most European countries) or at the farm. This is evident in the Netherlands where 10 to $13 \%$ of the Halal meat is bought directly from the farmer and slaughtered on the farm or at home [20]. The same practice is common in France and Belgium [20]. Many opinions in regard with stunning are still controversial. Many opponents of pre-slaughter stunning have often cited the possible death of the animal following stunning and before exsanguination which makes the pre-slaughter stunning transgress the Islamic dietary law [27]. Others attribute the retention of more blood in the carcass of animals to pre-slaughtering stunning. Nevertheless, several studies have demonstrated that there is no difference in terms of the total blood lost at exsanguination between animals slaughtered either with or without pre-slaughter stunning [28] [29]. These misconceptions yield to a lack of consensus within the Muslim community and pave the way to fraudulent activities in the Halal meat supply chain. Overall, there are different interpretations with regard to the slaughtering process in terms of the acceptance of machine slaughtering and stunning [30] but it is beyond the scope of this paper to discuss in details the Sharia requirements for stunning.

The post-slaughtering stages include the process of packaging, labeling and transporting the livestock [22]. All aforementioned activities need to comply with the Islamic Sharia [31]. Given that logistics is defined as all activities which facilitate the movement of the right product at the right time, at the right quantity, with the right descriptions and in good conditions [32], Halal status should be ensured during any activities and must adhere to the several Sharia principles.

The transportation process is a very important step to ensure the integrity of Halal logistics. It must be guaranteed that there is no cross-contamination of Halal meat and meat products with non-Halal substances such as pork carcasses. The risk of cross-contamination may happen if there is no proper segregation between Halal and non-Halal products and when the same container is jointly used for both [33]. Research has repeatedly underpinned the need for physical segregation of Halal 
products to prevent any intentionally or unintentionally direct contact with elements that can taint Halal status [34] [35]. Thus, this could lead customers to doubt if the product is really Halal, which will result in rejection of the Halal product. This could be also accentuated by the perception of Muslim consumers to the high risk of contamination especially for refrigerated and bulk products (e.g., meat) [34]. In a similar vein, since the avoidance of doubt is an important concern for Muslims in both Muslim and non-Muslim countries [11], Manufacturers and suppliers can mitigate this risk by the dedication of an entire transportation system for this type of logistics activity [33]. In doing so, they will reduce the risk of cross-contamination and ease the delivery process to their customers [33].

However, the preferred level of Halal food segregation is different between Muslim and non-Muslim countries. According to Tieman et al., the Halal flaws are less frequent in Muslim countries than the non-Muslim countries, where an extensive segregation to the last mile is needed [34]. Plus, Halal logistics is more complex and costly in these countries due to the smaller volumes of Halal products destined to Muslim minorities. In view of that, [34] shows that to satisfy 80 percent of the Muslims in the Netherlands, the non-mixing of Halal and non-Halal meat in the same fridge and on the same load carrier or pallet are required for the supermarket, transport, and storage. With regard to export and import operations via sea or airport, the segregation of Halal and non-Halal meat in the same carton box is required to satisfy the already mentioned percentage.

Knowing that almost all food producers outsource their transportation activities to the third party logistics (3PL) service providers due to the low-cost operations it brings and the need to satisfy customers of Halal food products in every part of the world, it is extremely difficult and challenging to assure no breakage of Halal procedures during the transportation of the products [22]. Most logistics service providers are reluctant to provide a dedicated transport fleet for Halal meat because the volume of Halal meat for the domestic market is small [16]. As a result, they do combine the shipment of Halal meat with non-Halal meat to achieve economies of scale. Although a combined shipment of Halal and non-Halal meat can be acceptable when there is some effective separation (e.g., the use of a curtain or special cage), the cross-contamination can be minimized but not completely avoided.

Furthermore, Halal logistics is still in infant stage even in Malaysia which aspires to become the Halal hub in the future [32] and there is no a successful model of a logistics company practicing total Halal logistics [5]. This refers to the lack of the knowledge and experts in conducting conveniently Halal logistics. Plus, the efforts of educating and training logistics service providers about Halal logistics are still limited and insufficient [5]. Similarly, some logistics companies consider the training provided by Halal authorities insufficient, not progressive or irrelevant to 
their business [5]. As interestingly aside from this, there is a lack of collaborative efforts among the logistics service providers. The integration between conventional logistics and Halal logistics service providers is weak and there is a possible inclusion of Haram or doubtful substances in the products in the supply chain and thus the information will not be disclosed or shared [5]. This could be also explained by the inconsistent practice of Halal logistics by the partners of the supply chain and hence any party which is not practicing Halal approach will temper the Halal integrity [5].

Food packaging (ranging from primary, secondary and tertiary packaging) plays a vital role in ensuring the protection, storage and hygienic of a product and it plays a key role in reducing the potential contamination [18]. In addition to the functional benefits of packaging, Halal meat and meat products must be appropriately packaged with packaging materials that are in accordance with Sharia law [36]. Likewise, the origin of the packaging materials still matters. The production of plastic packaging which uses animal-origin gelatins and the use of oil as a lubricant to assist the production of metal cans could void Halal status if they are derived from not properly slaughtered animals or from animals whose Halal status is questionable [32].

Food supply chains are highly exposed to the risk of economically motivated adulteration (EMA). It is defined as the fraudulent, intentional substitution or addition of a substance in a product for the purpose of increasing the apparent value of the product or reducing the cost of its production, i.e., for economic gains [37]. In view of this, tampering, misrepresentation of food ingredients or packaging, and the false or misleading statements made about the product are not a new phenomenon for meat. Indeed, the intentional mislabeling of non-Halal products as Halal in order to mislead consumers into buying such products is considered as an offense [27]. This is consistent with Mueller who compared the profits from food supply chain fraud to cocaine trafficking, with fewer risks [38]. Besides, the adulteration of pork is not uncommon in Halal meat and meat products and porcine derivatives are the most frequent non-Halal materials fraudulently used by meat processors [3]. This is because they are cheap and readily available [39]. Also, the adulteration and mislabeling of Halal meat is not restricted to non-Muslim countries (e.g., the European Union countries). Nowadays, there are some Muslim countries that are concerned with meat adulteration and Halal certification since meat is imported from various non-Muslim countries such as USA, Europe, and China, even so, certifications are not necessary when meat is sold fresh at easily recognizable joints [3]. In this context, [40] conducted a test of 143 processed Halal meat (beef and poultry) products in Malaysia for the presence of non-Halal proteins from pigs, rats, cats, donkeys, dogs and other undeclared permitted species. They found $78 \%$ of mislabeled products and buffalo DNA was detected in 40 out of 58 products labeled as beef, while 33 out of the 58 products contained undeclared chicken. 
Even though Halal logo or certificates contribute to reassure Muslims about the compliance of food products they consume to Islamic dietary guidelines, consumers are still skeptical about the authenticity of Halal logo or certificates [4]. Several cases decoy the trust of Halal consumers in many countries and among them Malaysia. Many food traders have been caught displaying fake certificates or self-made Halal logo which tarnished the reputation of Halal industry [4]. Besides, the fake and unauthorized certifications are explained by the inefficient, time consuming and costly certification processes [41] [42] and the corruption among certification authorities [43]. As such, [44] mentioned that procedures for Halal certification must be smooth and not too strict. [45] suggested that Halal logo or certificates must be authorized and issued by a credible Islamic organization in order to prevent fraudulent, fake and misleading logo or certificates.

It is acknowledged in the literature that among the most important issues in relation with Halal logistics are the lack of Halal certification authority and synergy by Halal authority agency in implementing the enforcement to logistics players [33]. In fact, there are scarce standardized Halal guidelines and an absence of a worldwide Halal certification such as a universal Halal logo. This yield to many challenges in maintaining Halal integrity throughout the supply chain [5]. Besides, there are prevalent issues regarding Halal regulation and enforcement in non- Muslim countries. Halal governance is under the supervision and control of several private entities [35] [46]. This has resulted in the existence of multiple bodies offering Halal certification services [22]. That is to say, any organization is able to provide or claim to provide Halal certification and inspection services for the manufacturers that want to tap the Halal market. That's why there is a growing skepticism among Halal consumers and manufacturers about the trustworthiness and credibility of these certification bodies [22].

\section{Halal Meat Supply Chain and Halal Critical Control Points (HCPs)}

\subsection{Halal Meat Supply Chain and Process Flow}

Generally, Halal food supply chain refers to the process of supplying Halal food from farm-to-fork while preserving its Halalness. According to [47], it is defined as the process of managing the procurement, movement, storage and handling of materials, parts, livestock, semi-finished inventory food and non-food and related information as well as documentation flows across the supply chain in accordance with the general principles of Sharia law. With regard to this context, the typical Halal meat supply chain consists mainly of the following various actors as shown in 
figure 1: farmers or breeders, abattoir, meat processors, wholesalers, distributors, retailers, and final consumers.

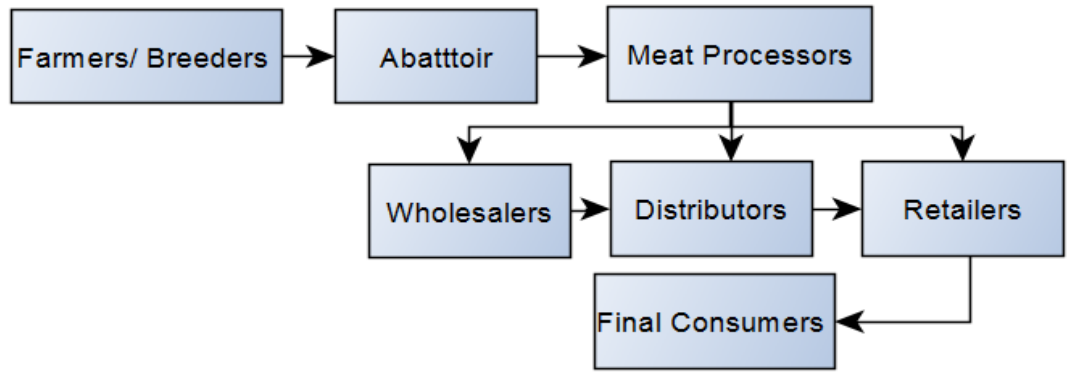

Figure 1. The Typical Halal Meat Supply Chain

The farmers or breeders start the upstream flow in the chain. In the preslaughtering stage, they play the role of livestock custodian (from young livestock to ready for slaughter). The background environment of farming should be assessed, including the distance from the vicinity of pig farms in case of a diverse livestock rearing, the welfare of the animals and the prescribed vaccinations. The livestock will be transported to the abattoir by the carriers and reasonable measures regarding the safety of animals should be ensured. In the abattoir, all slaughtering processes should be carried according to the Islamic law. As stated in figure 2, it is obvious that the real threat concerning the Halal critical control points within operations of the meat supply chain occurs at the slaughterhouse.

Five out of the ten critical control points identified in this study are found in the slaughtering stage. Besides, it is the responsibility of a Halal supervisor in the abattoir to crosscheck the health of the animals and separate the sick and injured ones. After a judgmental selection made by the Halal supervisor, the animals will be delivered for the slaughtering process. This is a key stage as differentiation between Halal and non-Halal meat occurs at this point [49]. The animal will be slaughtered one at a time. Stunning methods must be clearly administered and the time gap between stunning and slaughtering should be sufficient enough to let the animal die with bleeding in order to avoid the cross-contamination between Halal and non-Halal slaughtering. In case of a manual slaughter, which is the preferred method for cattle, the knife should be very sharp, clean and the slaughter should be performed by a Muslim and by a single swipe in order to reduce pain as much possible. Otherwise, the machines and equipment used for slaughter have to be cleaned and dry to avoid any contact with non-Halal products [50]. For the birds, mechanical slaughter is gaining acceptance among Muslims in Western European countries [20]. 
The invocation is a recitation of special prayer pronounced by a Muslim slaughterman while cutting the throat of an animal or while switching on the slaughtering machine. In addition, one Muslim slaughter person is positioned behind the machine to perform the slaughter if the machine misses a bird or if the cut is inadequate for proper bleeding [20].

After the complete bleeding, the animal will be skinned and its internal organs will be then removed. In this step, the meat inspector will perform the necessary inspection of the internal organs to check for any abnormalities in the cattle. The same applies to the scalding of poultry but without the need for an internal inspection. A trained slaughter person is preferred for efficiency and minimization of skin and carcass damage [47]. Immediately after that, the Halal logo will be stamped on the carcass using a special ink before it is sent to the chiller room to be cooled overnight [48].

A Halal dedicated transport logistics operator is preferred to carry out the shipment of carcasses from the abattoir to the meat processors.. This practice helps to reduce the risk of cross-contamination. At the meat processors, great care should be taken during cleaning, deboning, mincing, cutting, packaging and labeling. Packaging materials should be in accordance with the Halal guidelines. Plus, the final meat products are packed and Halal logos will be displayed on the different levels of packaging and the Halal meat will be stored in good working practices while waiting for shipment to wholesalers, distributors and retailers. Eventually, retailers must preserve the Halal integrity while meat is displayed for sale and not mixing Halal with non-Halal meat products. Any inquiry from the customer to verify the origin of the Halal meat should be welcomed by the seller by granting him the right to look at the Halal meat certificate. 


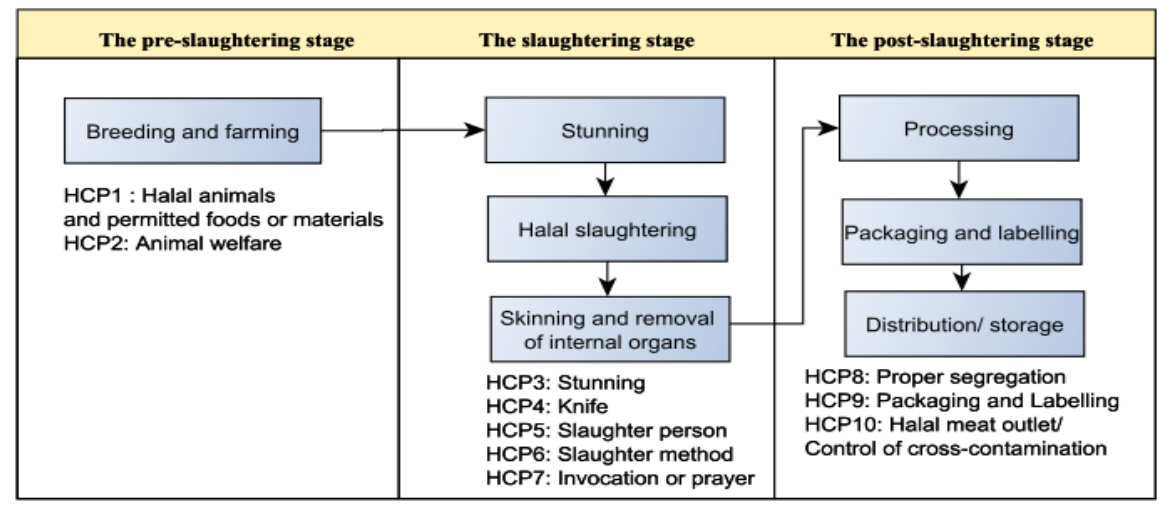

Figure 2. The Process Flow of Halal Meat and Halal Critical Control Points (HCPs) (Adapted from Riaz and Chaudry [47])

\subsection{The application of HACCP in Halal Meat Supply Chain}

The HACCP is a systematic approach which focuses on risk management and prevention to ensure food safety [15]. This implies to say that it aims to identify, assess and control hazards during production, processing, manufacturing, preparation, and use of food to ensure its safety when consumed [48]. Apart from management tools used to assure food safety, the focus of quality assurance schemes has become more comprehensive approaches allowing the assurance and safeguarding of process standards, relating for instance to animal welfare and certified production methods such as organic or Halal [20] [49] [50] [51] [52]. In this respect, Halal Assurance System (HAS) is presented as an internal mechanism to monitor, control, improve and prevent any non-compliance in Halal production [53]. HAS is based on the concept of Total Quality Management (TQM) [54] with the inclusion of three main elements; zero limit (Halal material used in the production), zero defect (Halal product is produced) and zero risk ( risks of Halal integrity breach). The principles of HAS are similar to HACCP approaches but with the added value of monitoring and control Halal status throughout the supply chain. Therefore, Halal control activities and assurance are essential to establishing a robust Halal food supply chain less vulnerable to Halal contamination [55]. Several critical points have been introduced by [56] at the slaughterhouse level to ensure the Halal status of meat. Nevertheless, an embedded Islamic dietary law into HACCP integrated system would require that the entire Halal meat chain is controlled according to HACCP principles with zero tolerance level at the implementation of corrective actions since any deviation (i.e., contamination with Haram materials) is deemed unacceptable from religious standpoint [57]. Figure 2 presents an integrated 
quality assurance system with Halal critical control points. These points pertain to the whole Halal supply chain and if they are identified, controlled and monitored, they will prevent the possibility of Halal non-compliance. The Halal critical control points are identified with their control measures then followed by a table which will summarize the monitoring procedures for each hazard and the required corrective and preventive actions.

Risks of the inclusion of non-Halal animals and unpermitted foods or materials (HCP1): The animal must be within the category of Halal species allowed to be consumed in Islam. Non-Halal-animals are not permitted even if they are slaughtered in a Halal manner [45]. No genetic cross-contamination from Haram species is allowed or the use of Genetically Modified technology to derive genes from nonHalal animals. Halal animal feed is important in the Halal chain. Muslims are prohibited from consuming animals that have eaten filth [20]. Besides, carnivores and animals fed with animal protein are strictly forbidden. Ingredient in the feed mill must not contain any genetically modified organism from unpermitted animals [20].

Risks associated with animal welfare (HCP2): Islam stresses out the humane treatment of animals before, during and after slaughter. Animals must be in good health, not stressed or excited before slaughter. Plus, they have to be well-nourished. The knife must be invisible to station [31]. No animal should be able to witness the slaughter of another animal [20].

Risks related to Stunning (HCP3): Since stunning is commonly used in many nonMuslim countries to make the animal insensible and thus to inflict less pain for it. However, stunning should not render the animal dead and if the animal is not slaughtered after a certain time it will regain consciousness.

Safety risks associated with a knife and related equipment (HCP4): The knife must be clean before slaughter, flaying, and dressing. Ensure all equipment properly maintained (knife sharpness, proportionate size, cleanness of rotary knife slaughter...). Utensils, equipment, and machinery (including all food contact surfaces) must be cleaned, sanitized and untainted by contact with Haram materials [58] [57]. Chemicals used for cleaning should be screened to avoid animal fat origin [56] and brushes should be Halal certified since it can be made of pig's hair [59]

The inclusion of non-Muslim slaughter (HCP5): Slaughter should be performed by an adult Muslim with a sound mind [56] and without gender distinction. Jews and Christians can be involved in Slaughter since the prophet Muhammed used to eat meat prepared by Jews and Christians [11]. The meat of an animal slaughtered by an idolater, a nonbeliever, or someone who has apostatized from Islam is not acceptable [56]. 
Safety risks associated with slaughter method (HCP6): It is necessary that slaughter method should be done humanely and avoids the unnecessary pain of the animal. The throat must be cut with a swift blow severing the carotids, jugulars, trachea, and esophagus and without reaching the bone. The animal skinning and removal of internals before deboning should be carried properly to maintain the safety of meat and preserve its quality. Halal carcasses should be cooled in a convenient and cold storage environment.

Risk of Invocation inaccuracy (HCP7): A supplication must be invoked while slaughtering the animal. In doing so, the slaughterman recalls his responsibility in respecting the prescribed method of ritual slaughter and in removing any doubt as to whom the animal is dedicated [60]. Besides, it reinforces the notion of sacrificing the animal to the Almighty God. Any invocation of another name than God renders the meat Haram [20].

Risks associated with segregation (HCP8): In the usual case, meat processors outsource the shipping of the carcasses from the slaughterhouse to their facilities or they rely on their own transport vehicles. The refrigerated containers of the vehicles used to transport carcasses must be cleansed thoroughly. The storage conditions of the meat should be inspected by the related inspector to ensure the appropriateness of storage condition (temperature, sound segregation in case of non-Halal logistics service providers). During transportation, Halal meat must be handled properly to avoid the risk of cross-contamination.

Safety risks associated with packaging and labeling (HCP9): Site assessment as part of assured scheme (e.g., temperature controlling, disinfecting, and equipment). All processing practices should be according to good working practices, and process activities should be aligned with Halal guidelines [15]. The packages and cartons should be labeled with appropriate statements (e.g., 'keep refrigerated') to inform distributors and retailers about the necessity of keeping the product cold [61]. For meat to be packaged and labeled properly as Halal, previous Halal control points should be evaluated by a reputable supervisory organization, which acts as a trusted third party and independent certification body [20].

Safety risks associated with Retail Management (Halal meat outlets) (HCP10): Retail management and distribution are a critical issue to prevent the risk of crosscontamination. Retailers have to ensure the Halal status of meat at their retail outlets. Besides, all retail management practices should be according to working practices and should preserve Halal integrity (e.g., proper refrigeration, checking the lifetime, separation of the expired meat products, and prevention of meat intermixing, etc.). 


\section{Table 1. Generic HCCP management applied to the Halal Meat Supply Chain}

\begin{tabular}{|c|c|c|}
\hline Control & Monitoring procedures & $\begin{array}{ll}\text { Corrective actions } \\
\end{array}$ \\
\hline HCP1 & $\begin{array}{l}\text { Regulator's approval, routine } \\
\text { reassessment, selection of persons by } \\
\text { the reference standards and by } \\
\text { legislative and religious requirements. }\end{array}$ & $\begin{array}{l}\text { Fiqh reasoning related to GM technology; reassess site } \\
\text { designation; document action taken }\end{array}$ \\
\hline $\mathrm{HCP} 2$ & $\begin{array}{l}\text { Site documentation, inspection record, } \\
\text { control of animal health documents, } \\
\text { and laboratory analysis report on the } \\
\text { disease from veterinary [62] }\end{array}$ & $\begin{array}{l}\text { Separate any injured, sick or dead animal before slaughter; avoid } \\
\text { any stressful or restraint; document actions taken }\end{array}$ \\
\hline HCP3 & $\begin{array}{l}\text { Halal supervisor ensures proper } \\
\text { stunning procedure. } \\
\text { Stunning monitoring record }\end{array}$ & $\begin{array}{l}\text { Review the time gap between stunning and slaughter, separate } \\
\text { any animal suffering a fatal stunning; avoid excessive stunning } \\
\text { voltage }\end{array}$ \\
\hline HCP4 & $\begin{array}{l}\text { Maintenance records of the hygiene of } \\
\text { used equipment, condition checking } \\
\text { record }\end{array}$ & $\begin{array}{l}\text { Review maintenance procedures; review workforce } \\
\text { responsibilities (e.g. protective wears); assess the cutting surface } \\
\text { (situation and lighting); document actions taken }\end{array}$ \\
\hline HCP5 & $\begin{array}{l}\text { Documentation of the person } \\
\text { responsible for the slaughter, training } \\
\text { record, competency monitoring record } \\
\text { and Islamic department slaughter } \\
\text { certificate [62] }\end{array}$ & $\begin{array}{l}\text { Review the workforce training since there are not enough trained } \\
\text { Muslim slaughtermen and the market of Halal is in its infancy } \\
\text { and demand is fleeting [56] }\end{array}$ \\
\hline HCP6 & $\begin{array}{l}\text { Regulator's approval and assessment, } \\
\text { visual monitoring, inspection of } \\
\text { internal organs report }\end{array}$ & $\begin{array}{l}\text { Take a regulatory control action to prevent any further improper } \\
\text { slaughter from occurring to other animals (e.g., blood vessels } \\
\text { raptures, muscular hemorrhage) } \\
\text { Major pathologies in internal organs: reject the carcass and } \\
\text { conduct a microbiological test } \\
\text { Assurance of clean and sanitary handling and preparation; } \\
\text { careful working practices }\end{array}$ \\
\hline HCP7 & Invocation checklist & None: Invocation is a secondary condition. \\
\hline HCP8 & $\begin{array}{l}\text { Transport monitoring, visual } \\
\text { monitoring, Halal certification }\end{array}$ & $\begin{array}{l}\text { Review procedures (selection of logistics service providers, own } \\
\text { transportation service); document actions taken; review carrier } \\
\text { Halal status }\end{array}$ \\
\hline HCP9 & $\begin{array}{l}\text { Cleaning and disinfection checklist, } \\
\text { microbiological control, in-house } \\
\text { inspection of materials, proper } \\
\text { maintenance of equipment, frequent } \\
\text { equipment inspection }\end{array}$ & $\begin{array}{l}\text { Training program for the workforce (e.g., personal hygiene, } \\
\text { sanitary dressing and proper product handling); review the } \\
\text { preventive maintenance program; refrigeration of perishable } \\
\text { vacuum packaged meat; proper holding and cooling } \\
\text { temperatures of meat; use of approved and Halal complied with } \\
\text { packaging materials }\end{array}$ \\
\hline HCP10 & Site documentation & $\begin{array}{l}\text { Adequate control of cross-contamination } \\
\text { Organizing in-house transport system, order bulk volume to have } \\
\text { less frequent delivery and full-truck-load, thus minimizing the } \\
\text { cross-contamination risk [63] } \\
\text { Review preventive procedures and document actions taken }\end{array}$ \\
\hline
\end{tabular}




\section{The traceability System Based on Blockchain and Internet of Things}

Since food products are scattered between the different actors of the supply chain, there are growing concerns to ensure food safety by the adoption of many internet of things technologies. Besides to being unsafe, the possibility for Halal food to be non-Halal is greater due to the travel distance whereby a lot of handling points will be included and the persistent risk of cross-contamination with non-Halal materials. To address the issues related to the stringent compliance of Halal products with Sharia law, there are a few preliminary publications in studies on the traceability of Halal meat products [31]. As a solution to that, [64] suggested a method to determine if the poultry is slaughtered according to Islamic way using an investigation of meat color. Junaini and Abdullah described a mobile-based support application for Muslims to identify Halal status [65]. Kassim et al. introduced a system to verify and recognize the information of products and thus to confirm their Halal status in real time from a real-time access to its database [66]. Bahrudin et al. proposed a comprehensive and suitable tracking and tracing technology using RFID to sustain the integrity of the Halal product and support the entire supply chain of Halal product process [47]. Iskandar et al. found that technologies such as TMS (Transportation Management System), WMS (Wharehouse Management System), EDI (Electronic Data Interchange) and GPS (Global Positioning System) are widely used among Halal logistics service providers [67]. Besides, [67] accentuated the compatibility of RFID's tracking and tracing characteristic with the Halal transportation guideline. Mohammed et al. present a framework in the development of an RFID-enabled HMSC network for enhancing traceability of Halal meat integrity throughout its entire supply chain [31]. All the previous research mentioned are the idea of using a centralized system which was latterly the only conceivable way to attain information transparency along supply chains [15]. However, there is not enough evidence about the accuracy and trustworthiness of the shared information in the traceability system and between Halal meat supply chain actors. As a result, this yields to an opaque system, information asymmetry, and many other issues. RFID- enabled traceability system is insufficient to guarantee the Halal integrity of meat. The manual retrieval and storage of information in the central database entail to many possibilities of misleading and falsification. In a similar way, it is problematic to ensure that what is termed Halal meat products are correctly compliant to Islamic dietary law and free from any misleading provenance histories. Hence, to mitigate the deficiencies of previous Halal traceability systems, we develop a conceptual framework of Halal meat $\mathrm{BC}$ system as illustrated in figure 3 . 


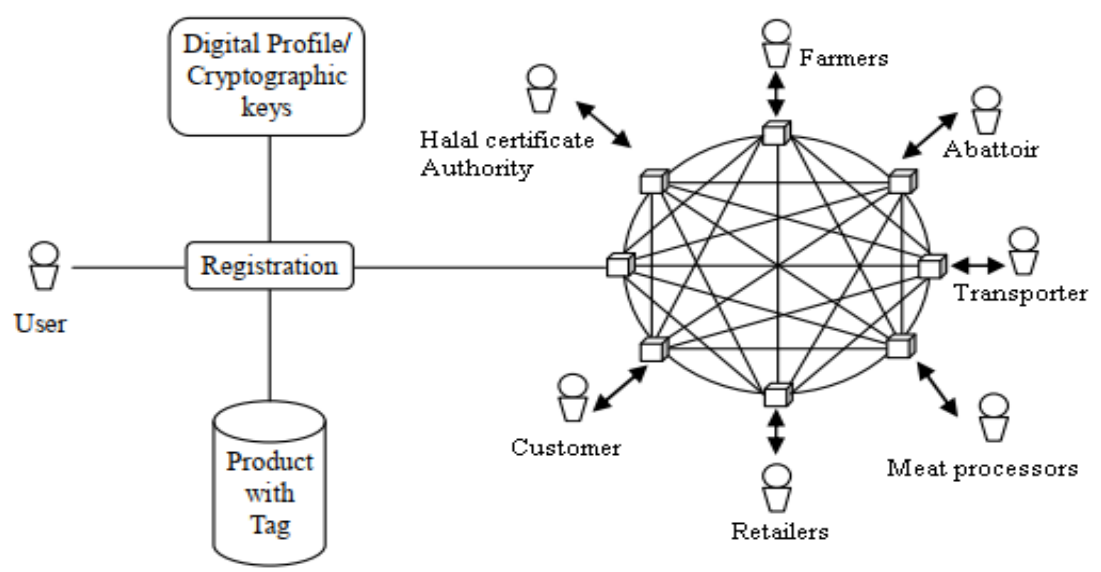

Figure 3. Conceptual framework of the Halal meat BC system (adapted from [15])

$\mathrm{BC}$ is a distributed ledger that becomes the foundation of a very robust system of trust, decentralization, and collaboration. The information through the system is publicly shared, replicated and permissioned. Besides, all the data in the $\mathrm{BC}$ is public, and any user has the access to add data in term of transaction which is identifiable data package in the system, to check and to copy this data at any time, but without the ability to change it [15]. Additionally, the $\mathrm{BC}$ validates the transaction without requiring intermediary assistance or the necessity of previously trusted entities [68]. Alternatively, the technology uses cryptographic or digital signature which is the trusted method to confirm the validity and finality of the transaction between the different parties [68]. Consequently, BC is a decentralized consensus system where all peers or partners come to an agreement regarding a business transaction and securely reach a state of harmony without the presence of the third party. Aside from being best-known for powering cryptocurrencies, BC technology revolutionizes and transforms the regulatory oversight of business transactions and thus it expands its seamless success to be incorporated into other industries. Similarly, this provides unprecedented opportunities for Halal industry to overcome the inherited problems (e.g., trust concerns, cross-contamination, frauds, tampering and falsifying, and fake Halal logos...) in the supply chain and logistics by the adoption of this ground-breaking and disruptive innovation.

Halal meat supply chain can be the best application scenario to show how actions in HACCP and previous RFID-enabled systems can be leveraged by the proposed BC-based traceability system. So, all Halal meat supply chain participants should 
register themselves in the peer to peer network and match their identities and digital profiles in back-end database which maintains an openly distributed ledger that can be accessed and inspected at any time and from any location [68]. After registration, each actor of the chain (i.e., node) will be provided with two different keys for encryption and decryption, also respectively known as a public key and a private key [69] to digitally sign each operation on the distributed ledger. The public key serves to identify the user within the system and the private key can be used for authentication when interacting in the network [70]. The different links involved in Halal meat supply chains are: Farming, Slaughtering, Meat processing, Distributing, Retailing, Certification

\subsection{Farming}

Farmers store in the BC information about each livestock. Each animal will be attached with wearable RFID tags or sensors and will be assigned to a digital profile. Besides, the use of RFID sensor tag can automatize the data entry process related to each livestock's physical condition (e.g., heartbeats, body temperatures, breath, sweat). Plus, these devices, if build precisely and used correctly, can provide a timely diagnosis of potential animal diseases, eventually decreasing economic losses [71]. The gathered information by RFID readers is sent to a host computer management system and there is a constant flow of up-to-date and real-time information in the digital profile of each livestock in the server. In doing so, the farm monitoring will be conducted easier than using writing notes, keeping farm diary, or using simple equipment without data-sharing function [71]. Animals' food intake and nutritional requirements will be monitored in such a way that the ingredients and the blend of feeds and fodder make it very safe and free from any Haram substance. The watering points or basin can be installed with water sensors, while smart contracts can autonomously fire, hence alerting the farmers about the record of water contamination (i.e., when sensors' values are outside certain threshold) and the necessity of separating contaminated livestock from others. In addition, the farmer maintains a medical record of each livestock relating to vaccination, illnesses, and medical treatments during the fattening period. All the information of given medical treatments and vaccination should not contain any non-Halal material (e.g., pork enzymes) [31]. The Halal meat supply chain starts at the farm and the farmer generates the genesis block and adds the required information about the livestock as described in the figure 1. The block is verified by the registers in the BC system before the next block being added to the chain. Each farmer has its own identifier (ID) in the distributed ledger since there might be many farmers who are supplying meat processors. In the generic block, the farmer puts all the aforementioned information to be shared with other supply chain actors and to be verified and added to the chain. 


\begin{tabular}{|l|l|}
\hline \multicolumn{2}{|l|}{ ID: CC01 } \\
Block 1 & Info details \\
\hline Info category & Beef \\
\hline Category & Halal \\
Feeding methods & Bovine ephemeral fever \\
Types of diseases/symptoms & 4 days \\
Treatment duration & Healed \\
treatment results & $10 \mathrm{Kg} / 8 \mathrm{mth}$ \\
Growing history/Kg & None \\
Enzyme history & June 19,2017 \\
Last update of info & $01 / 01 / 2017$ \\
Breeding date & $01 / 09 / 2017$ \\
Harvest date & \\
& \\
\hline Prev. Hash: abcdef0000a0b0bbcdcdfddfa56781ab \\
New Hash: 8bc9ef5080b0affbadadfedea56481cb \\
\hline
\end{tabular}

Figure 4. Typical generic block generated by the farmer (Adapted from [31])

\subsection{Slaughtering}

After transporting livestock to the abattoir, information data of each livestock will be gathered and stored automatically into its profile by scanning their tags through an abattoir's RFID-reader mounted gate. Violations related to the employment of unaccredited slaughtermen should be addressed by abattoir supervisors. In order to comply with the Halal slaughtering process, slaughtering stations have to be monitored by abattoir operators through installed cameras [31] to enable continuous control of the activities that pose a high risk to animal welfare and Halal integrity such as the stunning area. If the animal is not slaughtered according to Sharia law, it should be separated and marked as non-Halal. At the end of slaughtering, each segmented carcass is tagged with a new RFID sensor to keep a continuous record of $\mathrm{pH}$ values. The information can be collected by an RFID handheld reader and subsequently entered into a new block which is visible, transparent, and verified by all the participants in the BC system. This approach will enable Halal meat supply chains to attain chain-wide transparency. Many answers to questions regarding the slaughter stage will be provided and accessible to all actors through the BC such as the stunning method, the abattoir location, the responsible staff for slaughtering and meat inspectors, and the compliance to Halal requirements. Thus, the shared ledger can be viewed by meat processors, retailers, supermarkets, carriers and Halal certification authorities. 


\subsection{Meat processing}

After receiving carcasses, meat processors start by cleaning, deboning, and cutting the meat into slices to be repacked in smaller sizes and attached with new 2D barcodes. The handheld computer's barcode scanner will record the relevant information of the packed meat product. This information includes the processing environment, processing equipment, temperature control, basic information for processing enterprise and the involved personals [15]. The use of 2D barcode is explained by their ability to store a large amount of information as machine-readable and their operability as portable databases which can be scanned and decoded by camera-equipped mobile devices [72]. Besides, the transfer of RFID data to 2D labels resulted in very high accuracy in tracing the meat through the supply chain [75] . Meat processors may input the production data about their Halal meat products in the $\mathrm{BC}$ allowing potential consumers to access Halal meat's data by entering barcodes into the $\mathrm{BC}$ or using a mobile scanner. Not only that, Halal BC will faster the flow of information and thus of materials between the meat processors and their customers (e.g., retailers, supermarkets). This is attained by triggering automatic immediate actions based on the smart contract's terms such as meat products' order, release of funds, communication, informing of Halal certification authorities and authority organizations. As such, business transactions will be automatized in a secure and decentralized manner, reduce lead-times and solve Halal issues related to reputation damage. For instance, to counter the risks attributable to the shipment of Halal meat to customers, a smart contract can be the solution to ensure that the payment by the customers will be only released if the logistics service provider confirms the delivery of Halal meat in appropriate conditions, with proper segregation and without any cross-contamination with other non-Halal meat inside the refrigerated vehicle container [70].

\subsection{Cold chain distribution}

In the distribution process of Halal meat products, meat processors transfer the ownership of the processed meat products to distributors and retailers through the BC. Third-party logistics service providers are responsible for ensuring that Halal meat is delivered in a dedicated transportation unit that preserves Halal integrity. This is can be done by the use of vehicles equipped with a safety system (e.g., RFID reader, temperature sensor, GPS) which controls the temperature and the humidity in the different areas in the refrigerated containers. Besides to the $3 \mathrm{~T}$ principle (i.e., Time, Temperature and Tolerance), a zero tolerance practice is adopted to ensure that the religious requirements are stringently respected [57]. Relying on these technologies, real-time environmental data of Halal meat (e.g., temperature and humidity) can be added to their digital profiles and tags at a regular time intervals [15]. Not only that, sensors (e.g., GPS and temperature sensors) and smart contracts 
can automatize the process, update the meat products' digital profiles whenever anomalies are detected during the distribution phase, and send notification alert to the driver about the security threshold. In addition, the GPS system helps to position refrigerated trucks from remote distribution centers and help to optimize short delivery time in a way to guarantee the freshness of Halal meat products. The delivery and storage condition in the refrigerated container should be inspected and verified by the related staff in the BC to ensure that there is not improper physical segregation (i.e., in case there is not a Halal dedicated logistics service provider) which could, therefore, increase the trust in the Halalness of meat and avoid crosscontamination with Haram products. Eventually, BC can enhance the long-term relationship between logistics service providers and their customers in term of collaboration, goal congruence, information sharing, digitalization of paper flows, consolidation of Halal cargo, new value-added logistics and services, and more efficient settlement. Likewise, BC can also leverage the use of innovative logistics concept such as Halal cargo boxes.

\subsection{Retailing}

Retailers and supermarkets receive Halal meat products and store them in the BC. Customers can use their phone cameras or the available RFID reader to obtain the basic information about Halal meat products when they are shopping by scanning their barcodes. Thus, consumers will be able to transparently verify the whole history and provenance of Halal meat products and support their purchase decision-making. Besides, thanks to $\mathrm{BC}$ technology, retailers can have the access to a unique digital product memory for not only the Halal meat products but also for the animal from which meat is derived, the status of the used equipment, and all Halal inspections used throughout the entire supply chain. Similarly, BC provides a robust traceability system resistant to falsification and immutable. It ensures the Halal integrity of the meat and meets consumers' expectations and trust concerns by enabling each supply chain actors to retrieve easily the whole history of Halal meat products. Therefore, all Halal meat supply chain actors will be involved in a decentralized system which eradicates trust problems (e.g., fake Halal logos, Halal integrity breach, tampering, and misleading product's information) and promotes more openness, transparency, reliability and security [70].

\subsection{Halal Certification Bodies}

Throughout the different phases of the Halal meat supply chain, Halal certification bodies will benefit from BC through the easy editing of Halal meat supply chain and faster service to involved participants. Problems with regard to long Halal certification procedures, claims of Halal integrity breach and food safety hazards will be easily and instantly verified in the $\mathrm{BC}$ in a transparent way and with a rapid 
trace-back capability. Overall, BC can address the scarcity of a globally recognized Halal certification bodies by consolidating their efforts with other supply chain actors to respond to Halal issues and crisis.

\section{Conclusion}

In this paper, we addressed the different issues and problems pertaining to Halal meat supply chain management and logistics. To respond to the increased interest for Halal products and the growing concerns of Muslim consumers toward the integrity of Halal food in general and meat in particular, we proposed a new decentralized traceability system based on $\mathrm{BC}$ and internet of things (i.e., RFID). Besides, an application scenario was presented to integrate food safety and Halal under HACCP. To promote the efficiency and the success of the HACCP-based Halal quality-assurance system for application to slaughtering, meat processing and distribution, an environment that reduces the risk of contamination and Halal integrity breach is necessary to protect Halal meat from various hazards that render food not only unsafe but non-Halal and unfit for consumption by Muslims. Therefore, IoT technologies (e.g., RFID and sensors) are considered as key enablers for the traceability and the monitoring of Halal meat through all its intermediate phases and from farm-to-table till it reaches the final consumers. To address the problems of centralized systems in previous studies about Halal meat traceability, we propose a BC based-system which will provide more visibility over real-time information to all Halal meat supply chain partners on both the safety and the Halal integrity of meat products. This new traceability system overcomes the risks posed by the centralized information systems and brings more openness, transparency, reliability, and security. BC may have the potential to revolutionize Halal industry and promote the success of Halal meat supply chain by leveraging the collaboration between all parties of the value chain (i.e., farmers, meat processors, distributors and retailers, logistics service providers, and Halal certification bodies). Plus, it helps to ensure the higher compliance to Halal guidelines in farming, slaughtering, processing, distribution and the downstream requirements for more Halal products' authenticity and food safety. Future research may consider the development and discussion of BC-based traceability systems for other Halal markets, namely cosmetics, Halal tourism, and pharmaceuticals.

\section{Aknowledgement}

I would like to acknowledge and recognize the generous financial support of the project EFOP- 3.6.1-16-2016-00017- Internationalisation, creation of teaching, research and student supplies, development of knowledge and technology transfer as the means of intelligent specialization at Széchenyi István University. 


\section{References}

[1] D. Sack, Whitebread Protestants: Food and Religion in American Culture, St. Martin's Press, New Yourk, 2000.

[2] S.Z.S. Marzuki, C.M. Hall, P.W. Ballantine, Sustaining halal certification at restaurants in Malaysia, in: C.M. Hall, G. Stefan (Eds.), Sustaiable Culinary Systems, Local Foods, Innovation, Tourism and Hospital, $1^{\text {st }}$ Edition, Routledge Taylor \& Francis Group, London, 2013, pp. 256-274.

[3] K. Nakyinsige, Y.B.C. Man, a Q. Sazili, I. Zulkifli, a B. Fatimah, Halal Meat: A Niche Product in the Food Market, 2012 2nd Int. Conf. Econ. Trade Dev. IPEDR Vol. 36, IACSIT Press. Singapore Halal. 36 (2012) pp. 167-173.

[4] M.H. Zulfakar, M.M. Anuar, M.S.A. Talib, Conceptual Framework on Halal Food Supply Chain Integrity Enhancement, Procedia - Soc. Behav. Sci. 121 (2014) pp. 58-67. doi: $\underline{10.1016 / j . s b s p r o .2014 .01 .1108}$

[5] M. Syazwan, A. Talib, L. Rubin, V. Khor, Qualitative Research on Critical Issues In Halal Logistics, J. Emerg. Econ. Islam. Res. 1 (2013) pp. 1-20.

[6] M.H. Zulfakar, C. Chan, F. Jie, Institutional forces on Australian halal meat supply chain (AHMSC) operations, J. Islam. Mark. 9 (2018) pp. 80-98. doi: 10.1108/JIMA-01-2016-0005

[7] S. Kabir, Growing Halal Meat Demand: Does Australia Miss Out A Potential Trade Opportunity? Econ. Pap. A J. Appl. Econ. Policy. 34 (2015) pp. 60-75. doi: $10.1111 / 1759-3441.12101$

[8] J.A.J. Wilson, The halal phenomenon: An extension or a new paradigm? Soc. Bus. 4 (2014) pp. 255-271. doi: $10.1362 / 204440814 X 14103454934294$

[9] M.S. Ab Talib, S.S. Md. Sawari, A.B. Abdul Hamid, T. Ai Chin, Emerging Halal food market: an Institutional Theory of Halal certificate implementation, Manag. Res. Rev. 39 (2016) pp. 987-997. doi:10.1108/MRR-06-2015-0147 
[10] S.Z.S. Marzuki, C.M. Hall, P.W. Ballantine, Restaurant Manager and Halal Certification in Malaysia, J. Foodserv. Bus. Res. 15 (2012) pp. 195-214. doi: $\underline{10.1080 / 15378020.2012 .677654}$

[11] M.M. Hussaini, Islamic Dietary Concepts \& Practices, 1st Edition, Tyndale House Publishers, Bedford Park, 1993.

[12] N. Mohamad, C. Backhouse, A Framework for the Development of Halal Food Products in Proceedings of the 2014 International Conference on Industrial Engineering and Operations Management Bali, Indonesia (2014) pp. 693-702.

[13] W.M. Wan-Hassana, K.W. Awangb, Halal food in New Zealand restaurants: An exploratory study, Int. J. Econ. Manag. 3 (2009) pp. 385-402. doi: $\underline{10.1300 / \mathrm{J} 047 \mathrm{v} 15 \mathrm{n} 01}$

[14] M.S. Ab Talib, A.B. Abdul Hamid, M.H. Zulfakar, Halal supply chain critical success factors: a literature review, J. Islam. Mark. 6 (2015) pp. 44-71. doi: 10.1108/JIMA-07-2013-0049

[15] Feng Tian, A supply chain traceability system for food safety based on HACCP, blockchain \&amp; Internet of things, 2017 Int. Conf. Serv. Syst. Serv. Manag. (2017) pp. 1-6. doi:10.1109/ICSSSM.2017.7996119

[16] M. Hafiz Zulfakar, C. Chan, F. Jie, Factors Influencing the Operations of the Halal Meat Supply Chain in Australia, in: K.S. Pawar, M. Nkoma (Eds.), Proceedings of the 19th ISL International Symposium on Logistics, University of Nottingham, Nottingham, 2014, pp. 1-8.

[17] A. Mukhtar, M. Mohsin Butt, Intention to choose Halal products: the role of religiosity, J. Islam. Mark. 3 (2012) pp. 108-120.

doi: $10.1108 / 17590831211232519$

[18] J.M. Soon, M. Chandia, J. Mac Regenstein, Halal integrity in the food supply chain, Br. Food J. 119 (2017) pp. 39-51.

doi:10.1108/BFJ-04-2016-0150

[19] B.A. Alserhan, On Islamic branding: brands as good deeds, J. Islam. Mark. 1 (2010) pp. 101-106.

doi: $\underline{10.1108 / 17590831011055842}$ 
[20] K. Bonne, W. Verbeke, Religious values informing halal meat production and the control and delivery of halal credence quality, Agric. Human Values. 25 (2008) pp. 35-47. doi:10.1007/s10460-007-9076-y

[21] M. Tieman, The application of Halal in supply chain management: in-depth interviews, J. Islam. Mark. 2 (2011) pp. 186-195. doi: $\underline{10.1108 / 17590831111139893}$

[22] M.H.A. Kadir, R.Z.R.M. Rasi, S.S. Omar, Z.I.A. Manap, Halal Supply Chain Management Streamlined Practices: Issues and Challenges, IOP Conf. Ser. Mater. Sci. Eng. 160 (1) (2016) pp. 1-8. doi: $\underline{10.1088 / 1757-899 X / 160 / 1 / 012070}$

[23] A. Mohammed, Q. Wang, Integrity of an RFID-enabled HMSC Network, in: N. Walker (Ed.), Proceedings of the The Third International Conference on Digital Enterprise and Information Systems, Shenzhen, China, 2015, pp. 7986.

[24] Halal food- production, preparation, handling and storage- General guidelines (first revision), Standards Malaysia, ms.1500.2004 (2004)

[25] Halal food- production, preparation, handling and storage- General guidelines (second revision), Standards Malaysia, ms.1500.2009 (2009)

[26] M.H. Benkheira, La nourriture carne'e comme frontie're rituelle. Les boucheries musulmanes en France, Arch. Sci. Soc. Relig. 92 (1995) pp. 6788.

[27] A. Fuseini, S.B. Wotton, T.G. Knowles, P.J. Hadley, Halal Meat Fraud and Safety Issues in the UK: a Review in the Context of the European Union, Food Ethics. 1 (2) (2017) pp. 127-142. doi:10.1007/s41055-017-0009-1

[28] R. Khalid, T.G. Knowles, S.B. Wotton, A comparison of blood loss during the Halal slaughter of lambs following Traditional Religious Slaughter without stunning, Electric Head-Only Stunning and Post-Cut Electric HeadOnly Stunning, Meat Sci. 110 (2015) pp. 15-23.

doi: $\underline{10.1016 / j . m e a t s c i .2015 .06 .008}$ 
[29] M.H. Anil, T. Yesildere, H. Aksu, E. Matur, J.L. McKinstry, H.R. Weaver, O. Erdogan, S. Hughes, C. Mason, Comparison of Halal slaughter with captive bolt stunning and neck cutting in cattle: Exsanguination and quality parameters, Anim. Welf. 15 (2006) pp. 325-330.

[30] M. Tieman, Control of Halal Food Chains, Islam and Civilisational Renewal, 3 (3) (2012) pp. 538-542.

[31] A. Mohammed, Q. Wang, X. Li, A study in integrity of an RFID-monitoring HMSC, Int. J. Food Prop. 20 (2017) pp. 1145-1158. doi:10.1080/10942912.2016.1203933

[32] M. Syazwan Ab Talib, A. Bakar Abdul Hamid, Halal logistics in Malaysia: a SWOT analysis, J. Islam. Mark. 5 (2014) pp. 322-343. doi: 10.1108/JIMA-03-2013-0018

[33] N. Wazirah, R. Shah, A. Muhammad, S. Mohamad, Halal Transportation Providers for Supply Chain Management in Halal Industry : a Review Pengenalan : Penyedia Pengangkutan Halal Bagi, 1 (2016) pp. 1-12.

[34] A. Tieman, M \& Ghazali, Halal control activities and assurance activities in halal food logistics, in: Int. Halal Conf. 2012, Kuala Lumpur, Malaysia, 2012.

[35] A.-H. Lodhi, Understanding halal food supply chain, HFRC UK Ltd, London, 2009.

[36] K. Nakyinsige, Y.B.C. Man, A.Q. Sazili, Halal authenticity issues in meat and meat products, Meat Sci. 91 (2012) pp. 207-214. doi: $\underline{10.1016 / j . m e a t s c i .2012 .02 .015}$

[37] J. Spink, D.C. Moyer, H. Park, J.A. Heinonen, Defining the types of counterfeiters, counterfeiting, and offender organizations, Crime Sci. 2 (2013) p. 8. doi:10.1186/2193-7680-2-8

[38] T. Mueller, Letter from Italy, Slippery Business, Tha Trade in Adulterated Olive Oil, The New Yorker, August 13 (2007) pp. 38-45.

[39] A.A. Aida, Y.B.C. Man, C.M.V.L. Wong, A.R. Raha, R. Son, Analysis of raw meats and fats of pigs using polymerase chain reaction for Halal authentication, Meat Sci. 69 (2005) pp. 47-52. doi: $\underline{10.1016 / j . m e a t s c i .2004 .06 .020}$ 
[40] L.O. Chuah, X. Bin He, M.E. Effarizah, Z.A. Syahariza, A.K. ShamilaSyuhada, G. Rusul, Mislabelling of beef and poultry products sold in Malaysia, Food Control. 62 (2016) pp. 157-164. doi:10.1016/j.foodcont.2015.10.030

[41] M. Abdul, H. Ismail, H. Hashim, J. Johari, SMEs and Halal certification *, China-USA Bus. Rev. 8 (2009) pp. 22-30.

[42] N. Noordin, M. Hashim, Z. Samicho, Value Chain of Halal Certification System: A Case of the Malaysia Halal Industry Nurulhuda Noordin , Eur. Mediterr. Conf. Inf. Syst. (2009) pp. 1-14. doi:10.1108/JIMA-03-2014-0027

[43] N. Saleem, Many American meat exporters obtain halal certificate fraudulently, Gulf News. (2008).

[44] A. Evans, At The Cross-Roads, Halal Journal, 10 (2007) pp. 14-15.

[45] M.N. Riaz, M.M. Chaudry, The value of Halal food production, Inf. - Int. News Fats, Oils Relat. Mater. 15 (2004) pp. 698-700.

[46] S. Shafie, U. Malaya, K. Lumpur, Halal Certification : an international marketing issues and challenges, Proceeding Int. IFSAM VIIIth World Congr. (2006) pp. 1-11.

[47] S.S.M. Bahrudin, M.I. Illyas, M.I. Desa, Tracking and tracing technology for halal product integrity over the supply chain, Proc. 2011 Int. Conf. Electr. Eng. Informatics, ICEEI 2011 (2011). doi:10.1109/ICEEI.2011.6021678

[48] C. Ratanamaneichat, S. Rakkarn, Quality Assurance Development of Halal Food Products for Export to Indonesia, Procedia - Soc. Behav. Sci. 88 (2013) pp. 134-141.

doi: $10.1016 /$ j.sbspro.2013.08.488

[49] J.D. Wood, J.S. Holder, D.C. Main, Quality Assurance schemes., Meat Sci. 49 (1998) S191-203. doi: $\underline{10.1016 / \mathrm{S} 0309-1740(98) 90048-1}$ 
[50] A. Fearne, S. Hornibrook, S. Dedman, The management of perceived risk in the food supply chain: A comparative study of retailer-led beef quality assurance schemes in Germany and Italy, Int. Food Agribus. Manag. Rev. 4 (2001) pp. 19-36.

doi:10.1016/S1096-7508(01)00068-4

[51] A. Juska, L. Gouveia, J. Gabriel, K.P. Stanley, Manufacturing bacteriological contamination outbreaks in industrialized meat production systems: The case of E. coli O157:H7, Agric. Human Values. 20 (2003) pp. 3-19. doi:10.1023/A:1022416727626

[52] T.A. Ten Eyck, D. Thede, G. Bode, L. Bourquin, Is HACCP nothing? A disjoint constitution between inspectors, processors, and consumers and the cider industry in Michigan, Agric. Human Values. 23 (2006) pp. 205-214. doi:10.1007/s10460-005-6107-4

[53] A.A. Rahman, M. Abdul, Establishment of Traceability practices through Halal Assurance System ( HAS ) Implementation, 7 (2017) pp. 130-139. doi: $10.6007 / \mathrm{IJARBSS} / \mathrm{v} 7-\mathrm{i} 6 / 2951$

[54] S. Cerani, N. Bo, Possibilities and significance of the implementation of halal assurance system (HAS) in exixting quality system in food industry, Biotechnol. Anim. Husb. 25 (2009) pp. 261-266. doi:10.2298/BAH0904261C

[55] J. V. Vlajic, J.G.A.J. Van Der Vorst, R. Haijema, A framework for designing robust food supply chains, Int. J. Prod. Econ. 137 (2012) pp. 176-189. doi:10.1016/j.ijpe.2011.11.026

[56] M.N. Riaz, M.M. Chaudry, Halal Food Production, 1st Edition, CRC Press, New York, 2003.

[57] Kohilavani, W. Zzaman, W.W.N. Abdullah, A.Y. Tajul, Embedding Islamic dietary law into an HACCP approach for application to the poultry slaughtering and processing industry, Int. Food Res. J. 22 (2015) pp. 26842690 .

[58] A.N. Lau, M.H. Jamaludin, J. Mei Soon, Quality assurance and halal control points for the food industry, Nutr. Food Sci. 46 (2016) pp. 557-570. doi: $\underline{10.1108 / \text { NFS-03-2016-0026 }}$ 
[59] J. Fischer, Manufacturing halal in Malaysia, Contemp. Islam. 10 (2016) pp. $35-52$.

doi: $10.1007 / \mathrm{s} 11562-015-0323-5$

[60] A. M, Muslim attitudes to the slaughter of food animals, Anim. Regul. Stud. 3 (1981) p. 5.

[61] R.B. Tompkin, HACCP in the meat and poultry industry, Food Control. 5 (1994) pp. 153-161. doi: $\underline{10.1016 / 0956-7135(94) 90075-2}$

[62] T.A. Yang, N.A. Febrianto, W. Nadiah Wan Abdullah, A. Tajul Aris, A Decision Tree Based Approach for the Identification of Halal Critical Control Point for Slaughtering According to Islamic Dietary Law, Internet J. Food Saf. 14 (2012) pp. 48-53.

[63] M.H. Zulfakar, Australia's Halal Meat Supply Chain (AHMSC) Operations: Supply Chain Structure, Influencing Factors and Issues, RMIT University, Melbourne, Australia, 2015.

[64] M.A. Mohamad, S. Mansor, N. Ahmad, W.A.W. Adnan, I. Muhammad Wali, The reliability of halal product transportation using gps tracking system, J. Theor. Appl. Inf. Technol. 90 (2016) pp. 188-196.

[65] S.N. Junaini, J. Abdullah, MyMobiHalal 2.0: Malaysian mobile halal product verification using camera phone barcode scanning and MMS, in: Proc. Int. Conf. Comput. Commun. Eng. 2008, ICCCE08 Glob. Links Hum. Dev., (2008) pp. 528-532.

doi: $\underline{10.1109 / \text { ICCCE.2008.4580659 }}$

[66] M. Kassim, C.K.H.C.K. Yahaya, M.H.M. Zaharuddin, Z.A. Bakar, A prototype of Halal product recognition system, in: 2012 Int. Conf. Comput. Inf. Sci. ICCIS 2012 - A Conf. World Eng. Sci. Technol. Congr. ESTCON 2012 - Conf. Proc., 2012: pp. 990-994.

doi:10.1109/ICCISci.2012.6297170

[67] M. Iskandar, I. Tan, R.N. Razali, Z.J. Husny, The Adoption of Halal Transportations Technologies for Halal Logistics Service Providers in Malaysia, Int. J. Mech. Ind. Sciene Eng. 6 (2012) pp. 10-17. 
[68] W. Mougayar, The Business Blockchain, Wiley, New York, 2016.

[69] M. El Maouchi, Decouples: A privacy preserving solution for traceability in supply chains, M.Sc. thesis, Delft University of Technology, 2018.

[70] A. Rejeb, Blockchain Potential in Tilapia Supply Chain in Ghana, Acta Technica Jaurinensis 11 (2) (2018) pp. 104-118. doi: 10.14513/actatechjaur.v11.n2.462

[71] S. Neethirajan, Recent advances in wearable sensors for animal health management, Sens. Bio-Sensing Res. 12 (2017) pp. 15-29. doi:10.1016/j.sbsr.2016.11.004

[72] D. Buskirk, R. Clarke, D. Grooms, K. Kirk, Development of a Farm To Consumer Traceability Model, 2011. 